\title{
Produksi dan Kandungan Antosianin pada Padi Beras Merah setelah Pemberian Pupuk Nanosilika
}

\author{
Production and Content of Anthocyanins in Red Rice \\ after Giving Nanosilika Fertilizer
}

\author{
Skolastika Dara Sabatini ${ }^{1}$, Rini Budihastuti ${ }^{1}$, Sri Widodo Agung Suedy ${ }^{1 *}$, Agus Subagio ${ }^{2}$ \\ ${ }^{1}$ Program Studi Biologi, Fakultas Sains dan Matematika, Universitas Diponegoro, Semarang \\ ${ }^{2}$ Program Studi Fisika, Fakultas Sains dan Matematika, Universitas Diponegoro, Semarang \\ *Email: swasuedy@live.undip.ac.id
}

Diterima 26 Februari 2021 / Disetujui 28 April 2021

\begin{abstract}
ABSTRAK
Silika (Si) merupakan unsur penting yang dibutuhkan tumbuhan terutama familia Poaceae guna mendukung pertumbuhan dan produksinya, termasuk tanaman padi beras merah. Kandungan antioksidan dalam bentuk antosianin yang berkhasiat bagi kesehatan manusia menjadikan padi beras merah salah satu sumber pangan fungsional. Penelitian ini bertujuan untuk mengetahui pengaruh aplikasi pupuk nanosilika pada produksi dan kandungan antosianin padi beras merah. Penelitian menggunakan Rancangan Acak Lengkap dengan satu faktor yaitu perlakuan konsentrasi pupuk nanosilika $(\mathrm{P} 0 / \mathrm{kontrol}=$ konsentrasi $0 \mathrm{~mL} / \mathrm{L}, \mathrm{P} 1=$ konsentrasi 2,5 $\mathrm{mL} / \mathrm{L}, \mathrm{P} 2=$ konsentrasi $5 \mathrm{~mL} / \mathrm{L}, \mathrm{P} 3=$ konsentrasi7,5 mL/L, dan $\mathrm{P} 4=$ konsentrasi $10 \mathrm{~mL} / \mathrm{L}$ ), dengan 5 ulangan. Media tanam menggunakan tanah sawah dari Tembalang. Tempat media tanam menggunakan ember diameter $31 \mathrm{~cm}$ volume $5 \mathrm{~L}$. Aplikasi nanosilika dengan penyemprotan sebanyak $10 \mathrm{~mL} /$ pot yang dilakukan pada 10, 20, 30, 40, 50, 60, dan 70 HST. Paramater diamati meliputi: panjang malai; jumlah gabah/malai; persentase gabah isi; persentase gabah kosong; berat gabah/rumpun, jumlah gabah/1g, serta kandungan antosianin yang diamati pada 90 HST. Analisis data menggunakan ANOVA dilanjutkan dengan DMRT dengan taraf kepercayaan 95\%. Penelitian menunjukkan hasil bahwa perlakuan nanosilika dari P1 sampai P4 berpengaruh meningkatkan produksi dan kandungan antosianin padi beras merah, dimana perlakuan nanosilika sebesar 10mL/L (P4) memperlihatkan pengaruh tertinggi pada produksi serta kandungan antosianin padi beras merah.
\end{abstract}

Kata Kunci: konsentrasi, silika, produksi, malai, gabah

\section{ABSTRACT}

Silica ( $\mathrm{Si}$ ) is an important element needed by plants, especially in the Poaceae family to support their growth and production, including red rice. The content of antioxidants in the form of anthocyanins which are nutritious for human health makes red rice one of the sources of functional food. This study aimed to determine the effect of the application of nano-silica fertilizers on the production and anthocyanin content of red rice. The study used a completely randomized design with one factor, namely the treatment of the concentration of nano-silica fertilizer $(\mathrm{P} 0 /$ control $=$ concentration $0 \mathrm{~mL} / \mathrm{L}, \mathrm{P} 1=$ concentration $2.5 \mathrm{~mL} / \mathrm{L}, \mathrm{P} 2=$ concentration $5 \mathrm{~mL} / \mathrm{L}, \mathrm{P} 3=$ concentration $7.5 \mathrm{~mL} / \mathrm{L}$, and $\mathrm{P} 4=$ concentration $10 \mathrm{~mL} / \mathrm{L}$ ), with 5 replications. The planting medium uses paddy soil taken from Tembalang. Place the planting media using a bucket with a diameter of $31 \mathrm{~cm}$, volume $5 \mathrm{~L}$. Nano-silica applications with as much as $10 \mathrm{~mL} /$ bucket spraying were carried out at 10, 20, 30, 40, 50, 60, and 70 DAP. Parameters observed included: panicle length; the number of grain/panicles; percentage of filled grain; percentage of empty grain; the weight of grain/clump, amount of grain/1g, and anthocyanin content were observed at 90 DAP. Data analysis using ANOVA followed by DMRT with a confidence level of $95 \%$. The research showed that the nano-silica treatment from treatment P1 to P4 affected increasing the production and anthocyanin content of red rice, where the nano-silica treatment of $10 \mathrm{~mL} / \mathrm{L}(\mathrm{P} 4)$ showed the highest effect on the production and anthocyanin content of red rice plants. 


\section{PENDAHULUAN}

Silika (Si) adalah salah satu unsur kimia kedua terbanyak di lithosfer $(27,6 \%)$, dan diserap tumbuhan dalam bentuk asam monosilika $\mathrm{Si}(\mathrm{OH})_{4}$, atau $\mathrm{H}_{2} \mathrm{SiO}_{4}$. Tubuh serealia dan rumput-rumputan mengandung sekitar 0,2-2,0\% Si, bahkan tanaman tertentu dapat mengandung $10 \%$ Si. Silika membantu penguatan dinding sel epidermis dan berkas pembuluh, mereduksi transpirasi, serta menghambat infeksi fungi (Mitani and Ma, 2005; Makarim, dkk., 2007). Penelitian Tamai dan Ma (2003) menunjukkan bahwa tanaman padi adalah bioakumulator Si tertinggi, dimana oleh Broadley et al. (2012) disebutkan mencapai $39.1 \mathrm{mg} / \mathrm{g}$ berat kering tanaman padi.

Silika tidak termasuk unsur hara esensial bagi tanaman, namun merupakan beneficial element yaitu unsur yang jika ada akan berguna bagi pertumbuhan tanaman terutama pada tanaman padi serta anggota Poaceae yang lain. Seringkali Si tidak diperhatikan karena petani lebih memperhatikan pupuk hara makro, sehingga jarang atau tidak ada penambahan $\mathrm{Si}$ dalam kegiatan budidaya tanamannya. Pada produksi tiap ton/ha hasil padi memerlukan Si sebanyak 230-470kg/ha, sedangkan pada saat panen padi dapat terangkut Si antara 100$300 \mathrm{~kg} / \mathrm{ha}$ dari lahannya terutama yang berasal dari jeraminya. Hal ini diperparah lagi dengan kebiasaan petani yang tidak mengembalikan jerami ke lahan seusai panen. Penurunan ketersediaan Si pada lahan sawah tersebut diduga berhubungan erat dengan penurunan produktivitas tanaman padi (Markarim, dkk. 2007; Nugroho, 2009; Husnain, 2011).

Dilaporkan oleh Prasetyo dkk (2010) pada kurun waktu tahun 1970-2003 kandungan Si terus berkurang tersediaanya sekitar $20 \%$ pada tanah persawahan, sehingga penambahan $\mathrm{Si}$ penting untuk dilakukan. Hal ini didukung oleh laporan dari Balai Penelitian Tanah (2010) juga menunjukkan bahwa tanah di daerah tropis memiliki kandungan $\mathrm{Si}$ yang rendah karena reaksi pelapukan serta budidaya yang sangat intensif, sehingga laju kehilangan hara (termasuk $\mathrm{Si}$ ) cukup tinggi.

Unsur Si dalam tanah diserap akar dan ditranslokasikan ke daun. Serapan Si pada tanaman padi 6 kali lebih tinggi daripada serapan K, 10 kali lebih tinggi daripada serapan N, 20 kali serapan
$\mathrm{P}_{2} \mathrm{O}_{5}$ dan 30 kali lebih tinngi daripada serapan $\mathrm{K}$ (Yoshida. 1985). Unsur Si juga mampu mengikat hara lainnya dalam tanah, sehingga menjaga cadangan hara tanaman tidak mudah hilang terbawa air (Sommer, et al.,2006). Silika memperbaiki fungsi fisiologis tanaman, dan meningkatkan ketahanan tanaman terhadap serangan hama, penyakit serta terhadap kerebahan. Aplikasi $\mathrm{Si}$ terlihat signifikan ketika diaplikasikan pada stadia generatif yaitu perpanjangan bakal bunga; pada tanaman padi Si juga dapat meningkatkan jumlah gabah per malai dan bobot gabah isi per rumpun (Takahashi, 1995).

Pada penelitian ini diamati pengaruh aplikasi dari pupuk $\mathrm{Si}$ berbentuk nanosilika terhadap produksi dan kandungan antosianin padi beras merah (Oryza sativa L.). Kristamtini dan Purwaningsih (2009) berpendapat bahwa antosianin adalah senyawa fenolik kelompok flavonoid, dan berfungsi sebagai antioksidan bagi tumbuhan sendiri maupun manusia. Hosoda, et al. (2018) menyatakan bahwa beras berpigmen (beras hitam dan beras merah) mengandung antosianin dan proantosianidin yang berpotensi digunakan sebagai sumber antioksidan selain sebagai sumber pati. Peraturan Menteri Pertanian Republik Indonesia (2017) juga menyebutkan bahwa beras merah dimasukkan dalam kelas mutu beras khusus karena termasuk beras kesehatan.

Pemupukan $\mathrm{Si}$ berhubungan dalam metabolisme senyawa fenol, akibat dari terbentuknya kompleks Si-polifenol (Maksimovic, 2006). Jafari (2015) menambahkan bahwa Si dapat meningkatkan fenol, senyawa flavon serta aktivitas PAL yang merupakan kunci utama dalam biosintesis phenylpropanoid. Antosianin dapat terbentuk dari meningkatnya sintesis senyawasenyawa flavonoid tersebut.

Penggunaan pupuk nano yang berukuran super kecil $(1 \mathrm{~nm}=10-9 \mu \mathrm{m})$ memiliki keunggulan lebih reaktif, tepat sasaran target, serta efisien karena dibutuhkan dalam jumlah yang sedikit. Produk pupuk berteknologi nano diharapkan dapat menjadi terobosan teknologi untuk meningkatkan produksi pertanian, misalnya pada tanaman tebu yaitu meningkatnya jumlah daun, populasi tanaman, tinggi tanaman, diameter batang dan panjang ruas batang tebu (Widowati dkk, 2011; 
Pikukuh dkk, 2015). Hasil penelitian Amrullah (2015) menunjukkan jumlah anakan tertinggi pada tanaman padi yang diberi perlakuan 20 ppm nanosilika.

\section{METODE PENELITIAN}

Penelitian dilakukan di daerah Tembalang, Semarang, Jawa Tengah. Waktu penelitian di lakukan pada bulan April-Agustus 2016. Alat untuk mengukur total kandungan antosianin antara lain kertas saring, erlenmeyer, pipet tetes, tabung reaksi, waring blender, stirrer, rotary vacuum evaporator, shaking waterbath, dan spektrofotometer. Bahan yang digunakan adalah benih beras merah, tanah sawah sebagai media tumbuh, pupuk kompos, pupuk anorganik $\mathrm{N}$ (urea), TSP, $\mathrm{K}(\mathrm{KCl})$, pupuk nanosilika. Bahan yang digunakan untuk mengukur kandungan total antosianin antara lain aquadest, metanol absolut, larutan $\mathrm{pH} 1$ (buffer pottasum klorida) dan $\mathrm{pH}$ 4,5.(buffer sodium asetat).

Cara kerja meliputi persiapan media tanaman, perkecambahan benih padi, seleksi, serta penanaman bibit ke dalam ember plastik. Pemupukan tanaman menggunakan pupuk dasar (Urea, TSP, dan $\mathrm{KCl}$ ). Air dijaga selalu menggenang pada ketinggian $2 \mathrm{~cm}$ di atas permukaan tanah, 14 hari menjelang panen dibiarkan mengering. Penelitian ini menggunakan 5 perlakuan, yaitu perlakuan kontrol (P0; tanpa pemberian nano silika) dan perlakuan dengan pemberian nano silika dengan 4 taraf konsentrasi (P1: 2,5 mL/L; P2: $5 \mathrm{~mL} / \mathrm{L}$; P3: 7,5 mL/L; dan P4: $10 \mathrm{~mL} / \mathrm{L}$. Pembuatan larutan $\mathrm{Si}$ dengan cara melarutkan $(2,5 \mathrm{~mL} ; 5 \mathrm{~mL} ; 7,5 \mathrm{~mL} ; 10 \mathrm{~mL})$ pupuk nanosilika kedalam 1L air. Perlakuan pupuk Si dilakukan dengan cara penyemprotan pada seluruh bagian tanaman sebanyak $10 \mathrm{~mL} /$ pot. Penyemprotan Si dilakukan ketika tanaman berumur 10, 20, 30, 40, 50, 60, 70 HST. Pengamatan parameter produksi dan kandungan antosianin dilakukan setelah tanaman dipanen pada umur 90 HST.

Penelitian ini menggunakan Rancangan Acak Lengkap 1 faktor dengan 4 variasi perlakuan konsentrasi nanosilika, masing-masing dengan 5 ulangan. Analisis data menggunakan analisis variasi (ANOVA) dan Duncan's Multiple Range Test (DMRT) dengan taraf kepercayaan 95\%.
Parameter diamati pada penelitian ini adalah produksi padi beras merah dan kandungan antosianin pada beras merah. Parameter produksi meliputi panjang malai; jumlah gabah per malai; peresntase gabah berisi per malai; persentase gabah kosong per malai; berat gabah per rumpun dan jumlah gabah per 1g. Parameter kandungan total antosianin ditentukan dengan metode differential pH (Giusti dan Wrolstad, 2000). Beras dihancurkan dengan waring blender. Kemudian slurry dikeringkan dengan pengering beku. Bahan uji yang telah kering ditimbang, dimasukkan kedalam erlenmeyer. Sampel ditambahkan methanol $60 \mathrm{~mL}$ etanol/isopropanol dan diaduk dengan stirrer selama 1 jam, kemudian disentrifugasi 2000rpm untuk memisahkan filtrat dan residu. Filtrat dituang kedalam erlenmeyer dan residu diekstrak ulang dengan cara yang sama (dilakukan 3 kali ulangan, sampai diperoleh ekstrak yang bening). Semua hasil ekstraksi digabungkan, kemudian dievaporasi dengan rotary vacuum evaporator, pada suhu $40^{\circ} \mathrm{C}$ hingga diperoleh volume filtrat kurang lebih $25 \mathrm{ml}$. Filtrat ekstrak dimasukkan ke dalam labu takar 25 $\mathrm{ml}$, ditambah aquadest sampai volume $25 \mathrm{~mL}$. Diambil sebanyak $0,05 \mathrm{~mL}$ menggunakan pipet, dimasukkan dalam tabung reaksi. Tabung I ditambahkan $4,95 \mathrm{~mL}$ larutan buffer potassium klorida $0,025 \mathrm{M}, \mathrm{pH}$ 1. Tabung 2 ditambahkan $4,95 \mathrm{~mL}$ larutan buffer sodium asetat $(0,4 \mathrm{M}) \mathrm{pH} 4,5$. Masing-masing tabung didiamkan selama 15 menit. Absorbansi diperoleh dari setiap larutan pada panjang gelombang $520 \mathrm{~nm}$ dan $700 \mathrm{~nm}$ diukur menggunakan spektrofotometer. Digunakan buffer $\mathrm{pH} 1$ dan buffer 4,5 sebagai blangkonya (Widyawati, 2011). Absorbansi dari sampel yang telah dilarutkan $(\mathrm{A})$ ditentukan dengan persamaan:

$\mathrm{A}=\left(\mathrm{A}_{520}-\mathrm{A}_{700}\right)_{\mathrm{pH} 1,0}-\left(\mathrm{A}_{520}-\mathrm{A}_{700}\right)_{\mathrm{pH} 4,5}$

Kandungan antosianin total pada sampel dihitung dengan persamaan :

Total Antosianin $(\mathrm{mg} / \mathrm{l00g})=$

\section{A X BM X DF X 1000}

$$
\varepsilon \times l
$$

Keterangan :

BM : berat molekul Sianidin-3-glukosida $(448,8 \mathrm{~g} / \mathrm{mol})$

DF : faktor pengenceran

E : absorptivitas molar sianidin-3-glukosida

[ $26.900 \mathrm{~L} /(\mathrm{mol} . \mathrm{cm})]$

1 : tebal kuvet $(1 \mathrm{~cm})$ 


\section{HASIL DAN PEMBAHASAN}

Pengaruh pemberian Si terhadap produksi dan kandungan antosianin diperoleh hasil bahwa pemberian pupuk nanosilika memberikan pengaruh nyata/signifikan terhadap jumlah gabah permalai, persentase gabah berisi, persentase gabah hampa, dan kandungan antosianin, namun tidak berpengaruh nyata pada panjang malai, dan jumlah gabah per $1 \mathrm{~g}$.

Tabel 1. Rerata Produksi Padi Beras Merah dengan Perlakuan Konsentrasi Pupuk Nanosilika yang Berbeda

\begin{tabular}{ccccccc}
\hline $\begin{array}{c}\text { Perlakuan } \\
\text { Pupuk } \\
\text { Nanosilik }\end{array}$ & $\begin{array}{c}\text { Panjang } \\
\text { malai } \\
(\mathrm{cm})\end{array}$ & $\begin{array}{c}\text { Jumlah } \\
\text { gabah/malai } \\
\text { (butir) }\end{array}$ & $\begin{array}{c}\text { Gabah } \\
\text { isi/malai } \\
(\%)\end{array}$ & $\begin{array}{c}\text { Gabah } \\
\text { kosong/malai } \\
(\%)\end{array}$ & $\begin{array}{c}\text { Berat } \\
\text { gabah/rumpun } \\
(\mathrm{g})\end{array}$ & $\begin{array}{c}\text { Jumlah gabah } \\
\text { per 1g (butir) }\end{array}$ \\
\hline P0 & 21,00 & $73,40^{\mathrm{b}}$ & $79,00^{\mathrm{d}}$ & $21,00^{\mathrm{h}}$ & $20,80^{\mathrm{k}}$ & 45,80 \\
P1 & 22,40 & $101,40^{\mathrm{a}}$ & $84,20^{\text {cd }}$ & $15,80^{\mathrm{gh}}$ & $22,30^{\mathrm{k}}$ & 44,80 \\
P2 & 23,40 & $110,20^{\mathrm{a}}$ & $85,40^{\text {cd }}$ & $14,60^{\mathrm{gh}}$ & $25,80^{\mathrm{k}}$ & 44,60 \\
P3 & 23,60 & $112,20^{\mathrm{a}}$ & $86,40^{\mathrm{c}}$ & $13,60^{\mathrm{g}}$ & $28,40^{\mathrm{j}}$ & 44,60 \\
P4 & 24,80 & $124,40^{\mathrm{a}}$ & $91,00^{\mathrm{c}}$ & $9,00^{\mathrm{g}}$ & $31,60^{\mathrm{j}}$ & 40,00 \\
\hline
\end{tabular}

Keterangan: Angka yang diikuti huruf yang sama pada kolom yang sama menunjukkan pengaruh yang tidak berbeda nyata berdasarkan uji Duncan dengan taraf kepercayaan $95 \%$.

\section{Panjang Malai}

Malai merupakan sekumpulan bulir (spikelet) yang timbul dari buku batang paling atas, sehingga panjang malai adalah panjang dari buku terakhir sampai butir gabah yang paling ujung apada malai tersebut. Hasil penelitian menunjukkan bahwa pemberian pupuk nanosilika P1-P4 cenderung meningkatkan panjang malai tanaman padi beras merah sebesar $6,67 \%$ pada perlakuan nanosilika P1 $(2,5 \mathrm{~mL} / \mathrm{L})$ sampai $18,09 \%$ pada perlakuan $\mathrm{P} 4$ $(10 \mathrm{~mL} / \mathrm{L})$ daripada kontrol (P0), meskipun berdasar hasil uji ANOVA pada taraf kepercayaan 95\% menunjukkan pengaruh yang tidak berbeda nyata termasuk dengan kontrol (P0) (Tabel 1).

Pada penelitian ini, variabel panjang malai padi beras merah terlihat meningkat seiring kenaikan pemberian pupuk nanosilika, meskipun tidak berbeda nyata secara analisis statistik. Susilo (2015) menjelaskan bahwa, panjang malai tanaman padi sangat beragam, salah satunya tergantung pada varietas suatu tanaman, sementara pada penelitian ini hanya menggunakan 1 varietas atau jenis saja.

Meskipun pada panjang malai tidak menunjukkan perbedaan yang nyata, namun pada jumlah gabah per malai padi beras merah yang dihasilkan menunjukkan peningkatan yang berbeda nyata antara perlakuan nanosilika (P1-P4) dibandingkan kontrol (P0). Peningkatkan jumlah gabah tersebut karena proses fotosintesis yang optimal sehingga fotosintat menjadi lebih besar, di mana bulir-bulir gabah merupakan salah satu organ penyimpan fotosintat tersebut. Hal ini sesuai dengan penelitian Makarim, dkk (2007) bahwa penambahan Si meningkatkan kegiatan fotosintesis yang diikuti dengan peningkatan hasil fotosintatnya dan akan terlihat pada organ penyimpannya yaitu peningkatan jumlah gabah per malai. Selanjutnya menurut Mukasyafah (2011), pemberian Si akan membantu meningkatkan ketersediaan unsur $\mathrm{P}$ bagi tanaman, sehingga akan terjadi peningkatan translokasi fosfat dari akar ke batang kemudian daun yang dapat merangsang pembentukan bulir pada fase generatifnya.

\section{Jumlah dan Berat Gabah}

Pada parameter jumlah gabah per malai menunjukkan hasil yang berbeda nyata, bahwa perlakukan nanosilika P1-P4 mampu meningkatkan jumlah gabah per malai dibandingkan dengan kontrol (P0) dengan rerata kenaikan sebesar $52,65 \%$. Kenaikan terkecil sebesar 38,15\% pada perlakuan P1 dan dan tertinggi sebesar 69,48\% pada perlakuan P4. Detail jumlah gabah per malai pada masing-masing perlakuan disajikan pada Tabel 1. Hasil uji lanjut DMRT dengan taraf signifikansi 95\% menunjukkan perlakuan $\mathrm{P} 1, \mathrm{P} 2$, P3, P4 memiliki pengaruh yang berbeda nyata dengan P0 (kontrol).

Rerata persentase gabah berisi per malai menunjukkan kecenderungan meningkat pada pemberian pupuk nanosilika dari perlakuan P1-P4 
dibandingkan kontrol (P0) (Tabel 1). Hasil uji ANOVA pada taraf kepercayaan $95 \%$ terhadap persentase rerata gabah berisi per malai dengan pemberian pupuk nanosilika menunjukkan pengaruh berbeda. Hasil uji lanjut DMRT menunjukkan bahwa perlakuan nanosilika P3 (7,5 $\mathrm{mL} / \mathrm{L})$ dan $\mathrm{P} 4(10 \mathrm{~mL} / \mathrm{L})$.) berbeda nyata dengan P0 (kontrol). Persentase gabah bernas (berisi) meningkat sebesar 9,36\% pada P3 dan 15,19\% pada P4, sementara pada perlakuan P1 dan P2 kenaikan persentase rerata gabah berisinya berbeda tidak nyata dengan $\mathrm{P} 0$.

Pemberian pupuk nanosilika perlakuan P1-P4 cenderung menurunkan persentase gabah kosong pada padi beras merah, hal ini ditunjukkan dengan presentase rerata gabah kosong menurun dengan semakin tingginya konsentrasi pupuk yang diberikan (Tabel 1). Penurunan gabah kosong tertinggi ditunjukkan pada perlakuan $\mathrm{P} 4(10 \mathrm{~mL} / \mathrm{L})$ sebesar 57,14\%, sementara pada perlakuan P3 (7,5mL/L) menurun sebesar 35,24\% dibandingkan P0 (kontrol). Hasil uji ANOVA pada taraf kepercayaan $95 \%$ pada persentase rerata gabah kosong permalai dengan pemberian pupuk nanosilika menunjukkan pengaruh berbeda nyata. Hasil uji lanjut DMRT menunjukkan bahwa perlakuan P3 dan P4 memiliki pengaruh yang berbeda nyata dengan P0 (kontrol), sementara pada perlakuan $\mathrm{P} 1$ dan $\mathrm{P} 2$ penurunan persentase rerata gabah kosong berbeda tidak nyata dengan $\mathrm{P} 0$.

Pemberian pupuk nanosilika meningkatkan berat gabah perumpun dari padi beras merah, hal ini ditunjukkan dengan kenaikan rerata berat gabah per rumpun seiring dengan semakin tingginya perlakuan konsentrasi pupuk nanosilika yang diberikan (Tabel 1). Hasil uji ANOVA pada taraf kepercayaan $95 \%$ terhadap rerata berat gabah perumpun dengan pemberian pupuk nanosilika menunjukkan pengaruh yang berbeda nyata. Hasil uji dengan taraf kepercayaan $95 \%$ menunjukkan perlakuan P0 (kontrol) memiliki pengaruh yang berbeda dengan P3 $(7,5 \mathrm{~mL} / \mathrm{L})$ dan $\mathrm{P} 4(10 \mathrm{~mL} / \mathrm{L})$. Persentase kenaikan berat gabah per rumpun tertinggi ditunjukkan pada perlakuan P4 sebesar $52,02 \%$, sedangkan perlakuan P3 sebesar $36,82 \%$ dibandingkan P0. Sementara kenaikan berat gabah per rumpun pada perlakuan P1 dan P2 berbeda tidak nyata dengan $\mathrm{P} 0 /$. Pemberian pupuk nanosilika menunjukkan pengaruh yang tidak berbeda nyata termasuk dengan kontrol pada jumlah gabah berisi per 1 gram, berdasarkan hasil uji ANOVA pada taraf kepercayaan 95\%. Jumlah gabah per $1 \mathrm{~g}$ cenderung menurun pada pemberian pupuk nanosilika P1-P4 (Tabel 1).

Perlakuan pemberian pupuk nanosilika P1-P4 juga dapat meningkatkan gabah isi permalai atau menurunkan presentase gabah kosong, perlakuan yang terlihat nyata adalah pada perlakuan P3 dan P4 jika dibandingkan dengan kontrol. Sinar matahari berpengaruh terhadap produktivitas tanaman padi, terutama ditentukan oleh jumlah penyinaran selama masa pengisian biji yaitu minggu-minggu terakhir sebelum panen, dimana pada penelitian ini juga didukung dengan proses pengeringan tanaman 14 hari sebelum panen yang berguna dalam membantu pembentukan dan pengisian serta pengerasan bulir oleh kadar air yang menurun pada lingkungannya. Hal ini akan menyebabkan jumlah gabah isi yang lebih tinggi dan persentase gabah kosong yang rendah sebagaimana yang didapat dalam penelitian ini (Tabel 1). Dengan kondisi tersebut maka tanaman padi yang diberi perlakuan silika P1-P4 memiliki kemampuan yang lebih baik untuk menghasil produksi gabah yang lebih tinggi dibanding control, karena silika dalam bentuk pupuk nanosilika dapat meningkatkan efisiensi fotosintesis sehingga dapat meningkatkan hasil fotosintat yang disimpan dalam bulir sebagai tempat penyimpanan hasil fotosintesis sehingga jumlah gabah kosong dapat ditekan. Hasil ini sesuai dengan pendapat Sumardi (2010) yang menyatakan bahwa hasil biji didasarkan pada jumlah pati (asimilat) yang terakumulasi dalam spikelet. Penyebab gabah hampa adalah jumlah bulir permalai banyak tapi sumber kurang mendukung sehingga asimilat yang dihasilkan rendah dan kurang mencukupi untuk pengisian bulir.

Kondisi yang serupa juga terjadi pada variabel berat gabah per rumpun yang dihasilkan, karena perlakuan nanosilika telah meningkatkan jumlah gabah permalai dan gabah berisi permalainya sehingga berat gabah perumpun juga menjadi lebih tinggi. Hal ini sesuai dengan penelitian Kisbintari (2013), fotosintat yang dihasilkan dalam proses fotosintesis akan disimpan 
di dalam gabah. Semakin banyak fotosintat yang ditranslokasikan ke dalam gabah akan meningkatkan jumlah gabah isi yang dihasilkan, akibatnya berat gabah per rumpun pun juga akan meningkat. Pada penelitian ini perlakuan nanosilika P3 dan P4 menunjukkan hasil yang beda nyata dengan kontrolnya (Tabel 1).

Sementara itu pada variabel jumlah gabah per 1gram, perlakuan pupuk nanosilika terlihat menurunkan jumlah gabahnya namun jika dianalisa justru dengan jumlah gabah yang menurun menunjukkan arti bahwa ukuran gabahnya semakin besar, hal ini berkorelasi positif dengan berat gbah per rumpun yang juga menujukkan kenaikan seiring peningkatan konsentrasi perlakuan pupuk nanosilika yang diberikan. Kondisi ini menunjukkan bahwa perlakuan nanosilika dapat meningkatkan ukuran bulir, dengan pertumbuhan yang baik secara vegetatif yang didukung fotosintesi yang efisien maka sedikit banyak akan berkorelasi dengan perkembangan generatifnya. Sesuai hasil penelitian Susilo (2015) bahwa bertambahnya pasokan fotosintat akan meningkatkan jumlah gabah isi dan ukuran gabah.

Tabel 2. Rerata Antosianin Padi Beras Merah dengan Perlakuan Konsentrasi Pupuk Nanosilika yang Berbeda

\begin{tabular}{cc}
\hline Perlakuan Pupuk Nanosilika & Rerata Antosianin $(\mathrm{mg} / 100 \mathrm{~g})$ \\
\hline P0 & $108,50 \pm 3,72^{\mathrm{c}}$ \\
P1 & $118,96 \pm 2,22^{\mathrm{b}}$ \\
P2 & $118,83 \pm 3,25^{\mathrm{b}}$ \\
P3 & $124,36 \pm 3,69^{\mathrm{ab}}$ \\
P4 & $128,67 \pm 1,17^{\mathrm{a}}$ \\
\hline
\end{tabular}

Keterangan: Angka yang diikuti huruf yang sama pada kolom yang sama menunjukkan pengaruh yang tidak berbeda nyata berdasarkan uji Duncan dengan taraf kepercayaan $95 \%$.

\section{Kandungan Antosianin}

Perlakuan pupuk nanosilika P1-P4 meningkatkan kandungan antosianin, hal tersebut terlihat dari semakin tingginya perlakuan konsentrasi pupuk nanosilika yang diberikan P1-P4 seiring dengan kenaikan kandungan antosianin pada padi beras merah (Tabel 2). Hasil uji DMRT dengan taraf kepercayaan 95\%. menunjukkan perlakuan $\mathrm{P} 1, \mathrm{P} 2, \mathrm{P} 3, \mathrm{P} 4$. memiliki pengaruh yang berbeda nyata dengan perlakuan P0 (kontrol). Kandungan antosianin tertinggi terdapat pada perlakuan P4 $(10 \mathrm{~mL} / \mathrm{L})$ yaitu sebesar $128,67 \mathrm{mg} / 100 \mathrm{~g}$, sedangkan hasil antosianin terendah terdapat pada perlakuan P0 (tanpa nanosilika) yaitu sebesar $108,50 \mathrm{mg} / 100 \mathrm{~g}$. Rerata kenaikan kandungan antosianin dari perlakuan nanosilika P1-P4 sebesar 13,11\% dibandingkan P0 (kontrol).

Dari hasil pengamatan penelitian ini dapat dikatakan bahwa produksi dan kandungan antosianin tanaman padi beras merah menunjukkan kenaikan secara positif seiring dengan perlakuan konsentrasi pupuk nanosilika yang diberikan. Hasil penelitian ini juga menguatkan penelitian Sabatini dkk, (2017) bahwa perlakuan pupuk nanosilika memberikan hasil peningkatan tinggi tanaman dan jumlah anakan padi beras merah. Perlakuan Si sebesar $10 \mathrm{~mL} / \mathrm{L}$ memberikan hasil tertinggi pada variabel tinggi tanaman sampai $106,40 \mathrm{~cm}$ serta jumlah anakan sebanyak 40,20 anakan.

Tanaman padi beras merah yang baik pertumbuhan vegetatifnya akan memacu pertumbuhan generatif yang lebih baik juga, sehingga pertumbuhan organ-organ produksi tanaman untuk memberikan hasil yang lebih tinggi juga. Apabila dilihat Tabel 1, terlihat pengaruh positif dari pemberian pupuk nanosilika mampu meningkatkan panjang malai, jumlah gabah per malai; persentase gabah isi; persentase gabah kosong; berat gabah per rumpun, jumlah gabah per $1 \mathrm{~g}$, serta kandungan antosianin padi beras merah, maka dapat dikatakan bahwa perlakuan pemberian nano silika (khususnya perlakuan P3 $(7,5 \mathrm{~mL} / \mathrm{L})$ dan P4 (10mL/L) dapat memacu produksi serta kandungan antisianin tanaman padi beras merah 
sehingga menjadi lebih tinggi dibanding P0 (kontrol). Kondisi ini memperjelas bahwa silika merupakan unsur hara pembangun yang meskipun tidak termasuk kedalam unsur esensial, namun mampu merangsang serta meningkatkan produksi tanaman dan dapat menjadi unsur penting untuk beberapa tanaman tertentu, termasuk padi beras merah.

Silika diabsorbsi oleh tanaman dalam bentuk asam monosilikat $\mathrm{Si} \quad(\mathrm{OH})_{4}$, di akar $\mathrm{Si}$ dipolimerisasi menjadi $\mathrm{Si}$ amorf $(\mathrm{SiO} 2 . \mathrm{nH} 2 \mathrm{O})$ serta disimpan dalam sel-sel bulliform (Silica body). Selanjutnya dari akar $\mathrm{Si}$ ditranslokasikan oleh xilem bersamaan dengan air ke berbagai jaringan seperti batang, dan daun. Silika amorf ( $\mathrm{SiO} 2 . \mathrm{nH} 2 \mathrm{O})$ akan berasosiasi dengan selulosa pada sel epidermis jaringan tersebut. Silika memperkuat dinding sel epidermis sehingga mengurangi transpirasi berlebihan atau mengurangi cekaman air. Silika juga meningkatkan kekuatan mekanis jaringan sehingga bisa mencegah terjadinya kerobohan tanaman Ma and Yamaji (2006). Silika juga menyebabkan daun lebih kuat atau tegar dan merentang dengan baik dan secara tidak langsung bisa mengurangi dampak negatif overlapping tajuk (Yukamgo dan Yuwono, 2007). Ketegaran daun adalah hal penting dalam hubungannya dengan fotosintesis tanaman. Daun yang tegar dan tidak merunduk memungkinkan penetrasi sinar matahari ke daun atau bagian tajuk sebelah bawah menjadi lebih banyak, sehingga proses pemanenan cahaya matahari untuk fotosintesis berjalan maksimal sehingga proses pertumbuhan, perkembangan serta produksi tanaman menjadi lebih baik.

Pada variabel kandungan antosianin, perlakuan pupuk nanosilika dari P1-P4 terlihat meningkatkan kandungan antosianin secara signifikan dibandingkan kontrol (P0) (Tabel 2). Si dapat meningkatkan kandungan antosianin padi beras merah karena Si dapat memperbaiki proses fotosintesis yaitu melalui peningkatan klorofil, baik pada klorofil daun bendera maupun daun tanaman padi (Amrullah, dkk. 2014), serta meningkatkan sintesis fenol dan aktivitas PAL. Pembentukan polifenol dalam tanaman dimulai dengan proses fotosintesis melalui terbentuknya karbohidrat yang melalui jalur asam shikimat menjadi fenilalanin (Jafari, 2015). Hasil penelitian ini sesuai dengan penelitian Abdelkader (2016) yang menunjukkan bahwa kandungan antosianin pada bunga rosela meningkat $16,3 \%$ dengan tingkat perlakuan Si 0,00$5,25 \mathrm{~kg} / \mathrm{ha}$.

Kandungan antosianin pada beras merah sangat penting bagi kesehatan. Penelitian Widyawati, dkk., (2014) dan Azis, dkk., (2015) menunjukkan bahwa beras merah memiliki aktivitas antioksidan lebih tinggi dibandingkan beras hitam. Anhar (2013) menambahkan bahwa kandungan antosian pada beras merah tersebut mampu mencegah berbagai macam penyakit degeneratif seperti jantung koroner, kanker, diabetes, dan hipertensi.

Dengan ukuran yang lebih kecil (nano) dan pemberian baik melalui tanah serta daun seperti pada penelitian ini, kemampuan dari tanaman padi beras merah untuk menyerap $\mathrm{Si}$ akan semakin besar sehingga akan lebih banyak Si terabsorbsi dan mencukupi kebutuhan tanaman untuk metabolismenya. Hal ini sesuai dengan pendapat Ranjbar dan Shams, (2009) serta Widowati dkk, (2011) yang menyatakan bahwa pupuk berukuran nano lebih mudah diserap oleh tanaman dan lebih efisien dibanding pupuk kimia konvensional karena lebih reaktif, langsung mencapai sasaran atau target, serta hanya dibutuhkan dalam jumlah sedikit.

\section{KESIMPULAN}

Aplikasi penambahan $\mathrm{Si}$ pada lahan persawahan sangat penting untuk dilakukan diantaranya menggunakan pupuk nanosilika guna meningkatkan produksi tanaman dan kandungan antiosianin padi beras merah.

\section{DAFTAR PUSTAKA}

Abdeldeker, A. M. 2016. Effect of silicon application on roselle (Hibiscus sabdariffa L.) grown in a Vertisol in Egypt. JSSEM. 7 (4) : 45-52.

Amrullah. 2015. Pengaruh Nano Silika Terhadap Pertumbuhan, Respon Morfofisiologi Dan Produktivitas Tanaman Padi (Oryza sativa L.). [Disertasi].Institut Pertanian Bogor. Bogor. 
Amrullah, Sopandie, D., Sugianta dan Junaedi, A. 2014. Peningkatan Produktivitas Tanaman Padi (Oryza sativa L.) melalui Pemberian Nano Silika. PANGAN, Vol. 23 No. 1: 17 32

Anhar, A. 2013. Explorasi dan Mutu Beras Genotip Padi Merah di Kabupaten Pasaman Barat Sumatera Barat. Prosiding Semirata FMIPA Universitas Lampung. Hal. 97-101.

Azis, A., Izzati M., Haryanti S. 2015. Aktivitas Antioksidan dan Nilai Gizi dari Beberapa Jenis Beras dan Millet sebagai Bahan Pangan Fungsional Indonesia. Jurnal Akademika Biologi. Vol. 4 (1): 45-61.

Balai Penelitian Tanah. 2010. Mengenal Silika Sebagai Unsur Hara. Warta Penelitian dan Pengembangan Pertanian 32:19-20.

Broadley, M., Brown, P., Cakmak, I., Ma, J.F., Rengel, Z., and Zhao, F., 2012. Beneficial elements. In: Marschner, P. (Ed.), Marschner's Mineral Nutrition of Higher Plants, 3rd edition Elsevier, Amsterdam, pp. 249269.

Giusti, M.M. dan Wrolstad, R.E. 2000. Characterization of red radish anthocyanins. J. Food. Sci. 61 : 322-326.

Husnain. 2011. Sumber Hara Silika untuk Pertanian. Warta Penelitian dan Pengembangan Pertanian, 33(3) : 12-13.

Hosoda, K., Sasahara H, Matsushita K, Tamura Y, Miyaji M, and Matsuyama H. 2018. Anthocyanin and proanthocyanidin contents, antioxidant activity, and in situ degradability of black and red rice grains. Asian-Australas Journal of Animal Sciences. Vol. 31 (8): 1213 1220.

Jafari, S.M. 2016. Microecapsulation of saffron petal anthocyanins with cress seed gum compared wth Arabic gum through freeze drying. Carbpol.140 (2016) : 20-25.

Kisbintari, W., Edi P, Djoko M. 2013. Pengaruh Intensitas Cekaman Air Terhadap Pertumbuhan dan Kandungan Antosianin Padi Hitam dan Padi Merah. J. Agron Res. 2 (5) : 34-30.
Kristamtini dan Purwaningsih, H. 2009. Potensi Pengembangan Beras Merah Sebagai Plasma Nutfah Yogyakarta. Jurnal Litbang Pertanian 28 (3).

Ma, J. F. and E, Takahashi. 2002. Soil, Fertilizer, and Plant Silicon Research in Japan. Elsevier, Amsterdam.

Ma, J.F. and N. Yamaji. 2006. Silicon Uptake and Accumulation in Higher Plants. Journal Okayama University. Japan.

Makarim A, E. Suhartatik, A. Kartohardjono. 2007. Silikon: Hara Penting pada Sistem Produksi Padi. Iptek Tanaman Pangan 2 (2) : 195-204.

Maksimovic, J. 2006. Silicon Mudulates the Metabolism and Utilization of phenolic Compounds in Cucumber (Cucumis sativus L.) Grown at Excess Manganese. Centerfor Multidiciplanary Studies, University of Bergrade, Serbia.

Mitani, N and Ma, J. F. 2005. Uptake system of silicon in different plant species. Faculty of Agriculture. Kagawa University. Journal of Experimental Botany 56(414): 1255-1261.

Mukasyafah, U. H. 2011. Efektivitas Abu Sekam dan Zeolit Serta Pengurangan Pupuk NPK Terhadap Produksi Gandum Indonesia Pada Media Pasiran. [Skripsi]. Universitas Jember. Jember.

Nugroho B. 2009. Peningkatan produksi padi gogo dengan aplikasi silikat dan fosfat serta inokulasi fungi mikoriza arbuskular pada ultisol. [Disertasi]. Bogor (ID): Institut Pertanian Bogor.

Peraturan Menteri Pertanian Republik Indonesia. 2017. Kelas Mutu Beras. No. 31/PERMENTAN/PP.130/8/2017. Jakarta.

Pikukuh, P., Djajadi, Tyasmoro, S.Y., dan Aini, N., 2015. Pengaruh Frekuensi dan Konsentrasi Penyemprotan Pupuk Nano Silika (Si) Terhadap Pertumbuhan Tanaman Tebu (Saccharum officinarum L.). Jurnal Produksi Tanaman 3 (3) :249-258.

Prasetyo, T.B., Y. Syafrimen, Y. Edri. 2010. Pengaruh Pemberian Abu Batubara Sebagai Sumber Silika (Si) Bagi Pertumbuhan dan 
Produksi Tanaman Padi (Oryza sativa L.). Solum 7:1-6.

Ranjbar, M. and G.A. Sham 2009. Using of nanotechnology. J. Environtment Green, 3: 29-34

Sabitini, D.S., Budihastuti, R., dan Suedy, S.W.A. 2017. Pengaruh Pemberian Pupuk Nanosilika terhadap Tinggi Tanaman dan Jumlah Anakan Padi Beras Merah (Oryza sativa L.var. indica). Buletin Anatomi dan Fisiologi Volume 2 Nomor 2 Agustus 2017: 128-133.

Sommer, M., Kaczorek, D., Kuzyakov,Y., and Breuer, J. 2006. Silicon pools and fluxes in soils and landscapes-a review. J. Plant Nutr. Soil Sci. 169:310-329.

Sumardi. 2010. Produktivitas Padi Sawah Pada Kepadatan Populasi Berbeda. Jurnal Ilmu-Ilmu Pertanian Indonesia (JIPI). 12 (1) : 49-54.

Susilo, J. 2015. Pengaruh Jumlah Bibit perlubang Tanaman dan Dosis Pupuk, N, P Dan K terhadap Pertumbuhan dan Produksi Padi Sawah (Oryza sativa L.) dengan Metode SRI. Jom Faperta. 2 (1) : 1-15.

Takahashi, E. 1995. Uptake model and physiological Functions of silica. p. $420-433$. In Matsuo, T., K. Kumazawa, R. Ishii, K. Ishihara, and H. Hirata (Eds.). Science of Rice Plant, Volume Two, Physiology. Food and Agriculture Research Center, Tokyo.

Tamai, K., and Ma, J.F., 2003. Characterization of silicon uptake by rice roots. New Phytol. 158, 431_436.

Widowati, L.R., Husnain, dan W. Hartatik. 2011. Peluang Formulasi Pupuk Bioteknologi Nano. Badan Litbang Pertanian di Balai Penelitian Tanah. Bogor. 307-316.

Widyawati, P.S., Suteja A.M., Suseno T.I.P., Monika P., Saputrajaya W., Liguori C. 2014. Pengaruh Perbedaan Warna Pigmen Beras Organik terhadap Aktivitas Antioksidan. Agritech. Vol. 34 (4): 399-406.

Yukamgo, E, dan Yuwono, N.W. 2007.Peran Silikon Sebagai Unsur Bermanfaat pada Tanaman Tebu.Jurnal Ilmu Tanah dan Lingkungan, 7(2) : 103-116.
Yoshida, S. 1985. The physiology of silicon in rice.FFTC-ASPAC. Techn. Bull. 25:1-27. 